\title{
ENTREVISTA MICHAEL LOWY
}

Nota preliminar: não posso responder em nome de «o marxismo »...Existem mil marxismos, muitas interpetaçôes possiveis. Só posso dar minha opiniâo, enquanto marxista, ecosocialista, internacionalista.

\section{Revista Histedbr On Line - Como o marxismo pensa a questâo ecológica e a questão agrária?}

Michael Löwy - O marxismo nos da instrumentos fundamentais para entender a crise ecologica atual, e o desastroso processo de aquecimento global : resultam do carater profundamente irracional do sistema capitalista, baseado na expansão ao infinito, na produção de mais e mais mercadorias inúteis, na acumulação ilimitada do capital, e no desprezo por qualquer regra ou principio que seja um obstaculo à maximização dos lucros. O capitalismo é inerentemente contraditorio com a defesa do meio ambiente e do equilibrio ecológico do planeta. E um sistema intrinsecamente perverso que tem de ser superado se queremos evitar una catástrofe ecologica sem precedents na historia da humanidade.

Entretanto, acho que o marxismo deve rever algumas de suas colocações : por exemplo, é importante entender que a revolução socialista implica não só a mudança das relações de produção - a propriedade privada dos meios de produção - mas também a transformação radical das proprias forças produtivas. Deve se aplicar ao aparelho produtivo aquilo que Marx escrevia sobre o aparelho de Estado : os trabalhadores não podem se apropriar do aparelho burocrático capitalista e coloca-lo a seu serviço ; tem de « quebrá-lo » e substitui-lo por uma outra forma politica : um poder democrático dos trabalhadores. O que esta colocado então é uma mudança de todo o sistema produtivo, dos padrões de consumo, enfim, de tôda a civilização industrial capitalista moderna. $\mathrm{O}$ desafio do ecosocialismo, que a forma do marxismo no século 21, é de pensar num nôvo modêlo de civilização, mais além da mercadoria e do capital, baseado na solidariedade e no respeito pela « Terra-Mãe ».

Quanto à questão agraria: algumas das pistas mais interessantes para pensar a questão agraria no mundo e na America Latina em particular foram sugeridas pelo grande pensador marxista peruano, José Carlos Mariategui, que mostrava, ja em 1927-30, a importancia das tradições comunitarias camponêsas e indigenas - o que êle chamava de « comunismo inca » (encontramos exatamente a mesma expressâo em Rosa Luxemburgo) - para a luta pelo socialismo moderno.

Os camponêses , organizados na grande rêde «Via Campesina »- da qual faz parte o MST - são hoje em dia uma das forças mais avançadas e radicais no movimento altermundialista, no combate ao capitalismo agrario e às politicas neo-liberais, em defesa de uma agricultura camponêsa que respeite o meio ambiente. Os marxistas tem muito a aprender com estes movimentos. Não se pode reduzir o sujeito da transformaçâo social, em particular nos paises do Sul, unicamente à classe operaria fabril. Alias, em todas as grandes revoluções do século 20 - a mexicana, a russa, a chinesa, a vietnamita, a cubana - os camponêses tiveram um papel decisivo. 
2. Revista Histedbr On Line - Qual a pertinência e o alcance do conceito marxista de classe social? Como o marxismo analisa as transformações em curso no mundo do trabalho?

Michael Löwy - Os conceitos marxistas de classe social e de luta de classes são ao mesmo tempo um instrumento incontornavel de analise da realidade e um vetor da ação transformadora. Sem duvidas existem problemas essenciais que não se reduzem ao conflito de classes : a opressão da mulher, a dominação de etnias ou nações, a destruição do meio ambiente. Mas na medida em que estas questões estão ligadas, de uma forma ou de outra, com o sistema capitalista, existe uma articulação, uma convergência, uma relação dialética com a luta de classes.

As transformações do mundo do trabalho tomam formas muito diferentes no centro e na periferia do sistema. Existem algumas tendencies gerais : redução do pêso da classe operaria industrial, expansão do setor de serviços, proletarização do trabalho intellectual. Mas de uma maneira ou de outra, a grande maioria da população é composta de mulheres e homens que tem de vender sua força de trabalho para sobreviverem. Temos aqui o proletariado no sentido amplo, o conjunto das classes subalternas que vivem de seu trabalho e são submetidas à dominação do capital.

Nos paises periféricos encontramos uma enorme massa de pobres e excluidos, desempregados permanentes, condenados à uma sobrevivencia precaria na economia « informal »: é o « pobretariado », forma caracteristica do capitalismo dependente. A maioria desta multidão de deserdados vem do campo, de onde foi expulsa pelo desenvolvimento do agro-negocio capitalista, para concentrar-se nas margens das grandes cidades : é o «Planeta-Favela» de que falava Mike Davis. O grande desafio para os sindicatos, movimentos sociais e partidos de esquerda é conseguir organizar este « pobretariado ».

\section{Revista Histedbr On Line - Como as propostas marxistas podem contribuir para o desenvolvimento de um projeto educacional no Brasil?}

Michael Löwy - Do ponto de vista marxista, a educação é uma das prioridades de qualquer politica social. Um primeiro passo seria, como em Cuba ou na Nicaragua, uma grande campanha de alfabetização, mobilisando a juventude escolar para ir à todos os recantos do pais, utilisando a pedagogia ativa de Paulo Freire. Recursos enormes que hoje são desperdiçados com compra de armamentos inúteis - porta aviões ! - ou na subvenção à banqueiros e usineiros, deveriam ser dedicados ao orçamento da educação, em todos os niveis, desde o primario ao universitario ; é fundamental ampliar a rede de ensino publico gratuito, e marginalizar as empresas privadas, enorme sistema parasitario que se desenvolveu explorando as falhas da educação publica. E preciso garantir o acesso ao ensino secundário e universitário ao conjunto dos jovens brasileiros. Isto permitira não só criar centenas de milhares de postos de trabalho, mas contribuira para elevar o nivel cultural da população, aprimorar a qualificação profissional dos trabalhadores, ampliar substancialmente o publico leitor e reduzir a criminalidade juvenil. Enfim, seria 
importante associar os professores e os alunos, assim como seus sindicatos e associaçoes à uma reforma estrutural da educação, buscando superar a herança do elitismo, do autoritarismo e da exclusão social e/ou racial, e introduzindo métodos pedagógicos libertários.

\section{Revista Histedbr On Line - Quais os desafios, limites e possibilidades do marxismo na sociedade atual?}

Michael Löwy - Um certo tipo de marxismo, de corte positivista e dogmatico, transformado em ideologia de Estado pela burocracia dirigente dos assim chamados paises do "socialismo real" (à começar pela URSS) entrou em profunda crise com a queda - ou conversão ao capitalismo - destes regimes à partir de 1989. Mas o marxismo vivo, aquêle que inspirou Rosa Luxemburgo e Trotsky, Lukacs e Gramsci, José Carlos Mariategui e Farabundo Marti, Walter Benjamin e Ernst Bloch, Ernesto Che Guevara e os teologos da libertaçâo, nos dá, em sua diversidade, pontos de partida indispensaveis para entender a sociedade atual.

O marxismo não é um paradigma fechado, um sistema de "verdades cientificas" estabelecidas de uma vez por tôdas, um catalogo de "leis economicas" (ou historicas, ou politicas) invariaveis, mas um metodo dialético, humanista/historicista, de analise e transformação da realidade - uma realidade que obviamente não é a mesma no século 21 que na época de redação do Capital de Marx. Isto não impede que a sociedade em que vivemos ainda seja capitalista - na realidade, a dominação planetaria do capital é muito maior hoje em dia do que nos tempos de Marx e Engels - baseada na exploração, na dominação e na guerra.

Pessoalmente sou favoravel à um desenvolvimento do marxismo visando à aprofundar sua ruptura com os paradigmas da civilizaçâo (capitalista) moderna. Já Walter Benjamin, em seu Livro das Passagens inacabado, propunha uma reformulaçâo do marxismo de forma à liberta-lo de qualquer influência do positivismo e da ideologia burguêsa do «Progresso ».

Para mim o grande desafio para o marxismo no século 21 é integrar a questão ecológica. É o que tenta fazer o ecosocialismo, uma corrente de pensamento e de ação que se reclama ao mesmo tempo da defesa ecologica do meio ambiente e da analise marxista do capitalismo . Para os ecosocialistas, a lógica do mercado e do lucro capitalistas conduzem a destruição dos equilíbrios naturais, com consequências catastróficas para a humanidade. Em ruptura com a ideologia produtivista do progresso - em sua forma capitalista e/ou burocratica - e em oposição à expansão ilimitada de um modo de produção e de consumo incompativel com a proteção da natureza, o ecosocialismo representa um outro modelo de civilização, uma alternativa radical ao paradigma capitalista/industrial dominante.

\section{Michael Löwy}

